\title{
Utilization of Various Organic Wastes as Liquid Biofertilizer Carrier Agents to- wards Viability of Bacteria and Green Bean Growth
}

\author{
Novi Arfarita ${ }^{1 *}$, Tsuyoshi Imai ${ }^{2}$, Cahyo Prayogo ${ }^{3}$ \\ ${ }^{1}$ Faculty of Agriculture, University of Islam Malang 65144, Indonesia \\ ${ }^{2}$ Graduate School of Science and Engineering, Faculty of Engineering, Yamaguchi University, 755-8611, \\ Yamaguchi, Japan \\ ${ }^{3}$ Soil Science Department, Faculty of Agriculture, University of Brawijaya 65145, Indonesia
}

\section{Article history:}

Submission October 2020

Revised February 2021

Accepted December 2021

*Corresponding author:

E-mail: arfarita@unsima.ac.id

\begin{abstract}
The problem in the production of biofertilizers is that raw materials are cheap, easy to get and apply. Another problem is determining the viability of the consortium microbes in a biofertilizer formulation. This study aims to determine the bacterial viability of various liquid media originating from organic waste as a liquid biofertilizer carrier. Three indigenous bacterial strains under consortium for phosphate soluble (Pantoea ananatis strain 53 (BC32)), non-symbiostic Nitrogen fixation (Bacillus licheniformis strain S45) and stabilizing soil aggregate (Pseudomonas plecoglossida strain PR19) were added to liquid biofertilizer. The study evaluated 10 treatments using a randomized design with three replicates. The treatments are as follows: Peptone, molasses, Compost wash from seaweed waste, Vermiwash, molasses + glycerol, compost wash from seaweed waste + glycerol, vermiwash + glycerol, molasses + PEG (PolyEthylene Glycols)1\%, compost wash seaweed waste + PEG 1\%, and Vermiwash + PEG 1\%. This biofertilizer formulation (liquid) was kept for 16 weeks at optimum pH 5.5. VP3 (Vermiwash made from vermicompost + PEG 1\%) treatment showed the best viability of bacterial strains during the 16 -week storage period. The pathogenicity test using green bean seeds Vima-1 showed that all liquid formulations of biological fertilizers with the three consortium bacterial isolates did not show signs of diseases and demonstrated better growth than the control treatment. Compared to other treatments, the best growth of bacterial strains was detected with MP2 (Molasses + glycerol) treatment. Formulations using vermiwash and PEG appear to maintain bacterial viability in the formulation effectively. However, the formulation of molasses and glycerol exerts a stimulating effect on sprouts growth.
\end{abstract}

Keywords: Compost wash, Molasses, Pathogenicity test, Seaweed, Vermiwash

\section{Introduction}

Organic waste is a valuable component for implementing sustainable agriculture concepts because it can reduce the dependency on chemical fertilizers and build organic matter deposits in the soil. Increasing this component to soil impacts the increasing biological activity and improving the biochemical process of nutrient availability to crops [1]. Ideally, biofertilizer has good microbial viability during a long storage period without losing their nutrient quality [2]. Various sources of organic waste can be used as biological fertilizer carrier, such as molasses waste, vermicompost, and seaweed solid waste. Molasse is a well-known by-product of sugarcane waste. About $1.8 \mathrm{MT}^{-1}$ are being disposed of by sugarcane factories annually [3]. Vermicompost is derived from composting activities using earthworms as decomposers [4]. Seaweed solid waste is residues of seaweed factories. It is widely known to act as organic fertilizer, soil conditioner, or plant additive $[5,6]$. However, all three organic wastes have varied effects on crops [3, 4, 5, 6], depending on soil and environmental condition. Biofertilizer products which contain microbes are sensitive to 
environmental factors, such as: $\mathrm{pH}$ and temperature. These factors affect the microorganism viability and the maximum storage duration of the product. The vermicompost and seaweed waste can optimize the quality of biofertilizer products. However, there is limited information about using extracted material in biofertilizers.

The difficulty hinders the biofertilizer production in determining microbial viability and optimum growth under consortium formulations. Bacteria used in formulating biofertilizer has different role and functionality. They usually required different substrate conditions closely related to $\mathrm{pH}$ and temperature and those with a substrate for cell membrane stabilizer application such as PEG (Polyethylene Glycol) and Glycerol $[7,8]$. PEG and glycerol as an additive substrate for biofertilizer formulation remains limited particularly due to it being combined with extracted solid waste material.

In this study, the liquid biofertilizer-was formulated using three indigenous bacterial strains from Malang, Indonesia, obtained from previous studies: Pseudomonas plecoglossida strain PR19 and Pantoea ananatis strain 53 (BC32). B. licheniformis strain $\mathrm{S} 45$ free Nitrogen $(\mathrm{N})$ fixation bacterium known for its ability to fix $\mathrm{N}$ to soluble forms for plant uptake [9], P. plecoglossida strain PR19, is a stabilizing agent for soil aggregation bacteria [10]. The $P$. ananatis strain 53 (BC32), is recognized as phosphate-soluble bacteria [11]. These three bacteria were formulated in consortium formulations. When applied to the ecosystem, the consortium of these bacteria formed a complementary metabolic functionality.

Formulation-of these biofertilizers was produced with a combination of cheap, inexpensive, and abundantly available solid waste carriers with additive stabilizers for cell membranes (PEG and Glycerol). To control their viability, the $\mathrm{pH}$ of the substrate was modified. It is of utmost importance to ensure these indigenous bacterial consortium's survival and growth performance- Therefore, this study was conducted to observe the bacterial viability of various waste liquid media as biological fertilizer carriers within a 16-week storage period. This study further observed their effects on green bean (scientific name) growth and pathogenicity test. The green bean was used as the indicator crop to detect the impact of bacterial consortium on growth as recommended from previous research [12]. It was reported that green bean was also susceptible on a soil-born pathogen such as Rhizoctonia solani [13]. Green bean is one legume plant, and sprout is the phase most susceptible to soil-borne pathogens. Biofertilizer formulated in this study will be applied to the soil starting from the nursery and the condition does not cause disease, especially in the nursery which is a critical stage during a plant life cycle.

\section{Materials and Methods}

Compost wash was made from fermented solid waste seaweed agar factory in Malang CityIndonesia which has been decomposed then liquid form was collected following dilution with water followed by fermentation processes. Molasses is a viscous product resulting from refining sugarcane residue. Vermiwash is made from vermicompost obtained from earthworm cultivation. The solid tofu waste and liquid form was collected after being diluted with water. This was followed by the fermentation processes.

\section{Research design}

A randomize Complete Design (RCD) with 3 replications was employed. The types of bacteria used in this study are namely: B. licheniformis (non-symbiotic $\mathrm{N}$ fixing bacteria), $P$. plecoglossida (soil aggregate stabilizing bacteria) and $P$. ananatis (soluble phosphate bacteria). The treatments used were as follows (Table 1).

\section{Isolate purification}

Purification of isolates was conducted at the beginning of consortium culture before treating various biological fertilizer formulations. Purification of isolates was performed using the streak plate method. Each pure bacterial isolate was swabbed on Nutrient Agar (NA) media using a standard sterile needle and incubated for 24 hours at $33^{\circ} \mathrm{C}$. The single colony was then tested for its purity by gram staining. This was done by dripping sterile $\mathrm{H}_{2} \mathrm{O}$ on object-glass, rubbing one ooze of isolate onto the glass slide and drying it by passing over Bunsen. The samples were then dripped with crystal violet, flattened and flowed with running water. The same procedure was repeated for iodine. The samples were dripped with iodine, flattened and dried. Then, the samples were dripped with alcohol, washed with running 
Table1. List of treatments

\begin{tabular}{|c|c|c|}
\hline No. & Code & Treatments \\
\hline 1. & P0 & Control, Peptone \\
\hline 2. & RP1 & $\begin{array}{l}\text { Compost wash made from seaweed } \\
\text { waste }\end{array}$ \\
\hline 3. & RP2 & $\begin{array}{l}\text { Compost wash made from seaweed } \\
\text { waste + glycerol }\end{array}$ \\
\hline 4. & RP3 & $\begin{array}{l}\text { Compost wash made from seaweed } \\
\text { waste + PEG } 1 \%\end{array}$ \\
\hline 5. & MP1 & Molasses \\
\hline 6. & MP2 & Molasses + glycerol \\
\hline 7. & MP3 & Molasses + PEG 1\% \\
\hline 8. & VP1 & Vermiwash made from vermicompost \\
\hline 9. & VP2 & $\begin{array}{l}\text { Vermiwash made from vermicompost }+ \\
\text { glycerol }\end{array}$ \\
\hline 10. & VP3 & $\begin{array}{l}\text { Vermiwash made from vermicompost }+ \\
\text { PEG } 1 \%\end{array}$ \\
\hline
\end{tabular}

water and dried over Bunsen. After drying, the samples were stained with safranin, flattened before being washed with running water and dried. Finally, the samples were dripped with emersion oil and observed under a microscope with 1000x magnification.

\section{Identification of soil bacteria}

The three bacterial strains used in this study were from previous research. Two of the strains identified were phosphate-soluble bacteria ( $P$. ananatis strain 53 (BC32)) and non-symbiotic nitrogen fixation (B. licheniformis strain S45). The third strain had the functional property of soil aggregation stabilization and was later identified as P. plecoglossicida by $16 \mathrm{~S}$ rRNA. The Bacterial Genomic Mini prep Kit (MERCK) was used for bacterial DNA isolation and extraction. We amplified 16S rRNA Gene of the bacteria and then sorted them sequence. The first step involves DNA isolation and extraction. The DNA concentration was measured using PCR amplification of 16Sr RNA gene. Universal primers of bacteria for amplification were used 16S rRNA 5' CCAGCAGCCGTAATACG 3' and 5' ATCGGCTACCTTGTTACGACTTC 3', according to the previous research [14]. PCR mixing was processed after mixing the chromosomal DNA (10 ng of genomic DNA collected from each bacterial strain) with the master mix which contained primer, BSA, $\mathrm{MG}^{++}$and all dNTP's then initiated by the addition of taq- polymerase. The last step involved the purification of PCR products. The PCR products were observed with agarose gel electrophoresis, then purified using EXO SAP for sequence reaction. Purified PCR products were submitted to the DNA Centre Facility in Eijkman Institute for Molecular Biology-Jakarta for sequencing. The sequencing results were then uploaded into the GenBank using an online procedure. The $16 \mathrm{~S}$ rRNA gene sequence was compared to public databases available online at www.ncbi.nlm. nih.gov /GenBank/.

$P$. ananatis, and $P$. plecogloccicide are Gramnegative bacteria, while $B$. licheniformis is grampositive bacteria. Gram-positive bacteria are known to have a thicker layer of peptidoglycan compared to gram-negative bacteria. Gram-negative bacteria have a thick outer membrane composed of proteins, phospholipids, and lipopolysaccharides. Together with the peptidoglycan layer, they form a strong protective coat for the cells [15]. These characteristics of bacterial are also related to resistance to moderate-high temperatures. This is important especially for field applications, especially in tropical and drought climate conditions. From the gram staining, SNF 5 was in Bacillus, SPP 1 was Staphylococcus and SPE 20 was coccus.

\section{pH optimization test}

Determination of optimal $\mathrm{pH}$ for bacterial consortium growth, carried out using a Completely Randomized Design (CRD) by growing all bacterial isolates ( $P$. plecoglossicida, $B$. licheniformis, $P$. ananatis) under consortia scheme was placed on an Erlenmeyer tube containing $100 \mathrm{ml}$ Nutrient Broth Culture media with 5 different level of pH: 5.0, 5.5, 6.0, 6.5 and 7.0. The treatment was repeated 3 times, based on the following formula: $(n-1) \geq 15$; whereas: $t$ was the treatment and $n$ the number of replications). Value of $\mathrm{pH}$ was regulated by adding $\mathrm{HCl}$ or $\mathrm{NaOH}$. Determination of optimal $\mathrm{pH}$ for bacterial culture was carried out by measuring optical density (OD) of each treatment after a storage period of three days at room temperature. For three consecutive days, the-sample was observed every 12 hours for measuring bacterial growth by calculating the value of OD at $600 \mathrm{~nm}$ using a spectrophotometer (UV V is Genesys 150).

\section{Biofertilizer liquid formulation}

Production of liquid formulations was conducted by adding seaweed waste, molasses, vermiwash, peptone water, PEG, glycerol, and all three bacterial isolates ( $P$. plecoglossicida, $B$. 
licheniformis, $P$. ananatis) with treatment as described in the research design (Table 1). The ingredients were sterilized first except bacterial isolates. After cooling the liquid media, the bacterial culture of the consortium was mixed homogeneity with the media. Each treatment was inserted into a plastic bottle and stored in a in a dry room away from direct sunlight at $27^{\circ} \mathrm{C}$.

Observation of viability was carried out using the spread plate method and calculated using the total plate count $(\mathrm{CFU} / \mathrm{ml})$ method. Calculation of bacterial cell counts was carried out by TPC (Total Plate Count) method. Analysis of viability was carried out using Complete Randomize Design (CRD). A total of 10 treatments were tested. Each was replicated three times and was calculated using the formula $t(n-1) \geq 15$ [16]. Observation of viability during the eight weeks storage period was performed once a week and after a storage period of eight weeks to 16 weeks.

\section{Test of pathogenicity}

The liquid formulation of biological fertilizer was tested for its effects on the growth of green bean sprouts that have been sown for 2-3 days and selected for uniform growth with $\pm 1 \mathrm{~cm}$ length [12]. The selected mung bean sprouts were put in a test tube containing sterile media (Yoshida solution) and inoculated with liquid fertilizer formulations according to the treatment (Table 1). Each treatment was repeated four times using the formula $t(n-1) \geq 15$ [16]. The parameters observed in the pathogenicity test the presence of the disease, growth abnormalities and growth inhibition of the sprouts.

\section{Data analysis}

In this study, the statistical analysis used was a $5 \% \mathrm{~F}$ test to determine the effect of each treatment. If there was a sign, then a 5\% LSD (Least Significant Difference) test to determine the differences between treatment samples.

\section{Results and Discussion Purification of bacterial isolates}

This study confirms that $B$. licheniformis is $\mathrm{N}$ fixing bacteria (SNF 5), while $P$. ananatis is a $\mathrm{P}$ solubilizing bacteria (SPP 1). P. plecoglossicida was found to improve soil aggregate stabilization (SPE 20). The morphology of each bacterial colony can be seen in Figure 1. The morphology of the bacterial cells was observed from gram staining of bacteria aged 24-36 hours after rejuvenating from the previous isolates collection by $[9,10,11]$.

Pantoea ananatis has a wide $\mathrm{pH}$ range for their growth at 4.0-10.0 (Table 1) however, their optimal condition is at $\mathrm{pH} 7.0$ and at temperatures between $28^{\circ} \mathrm{C}-30^{\circ} \mathrm{C}$ (temperature range $15^{\circ} \mathrm{C}$ $37^{\circ} \mathrm{C}$ ) [17]. da Silva et al. [18] indicated that $P$. ananatis SCB4789F1 is beneficial for plant growth, which is shown by its ability to dissolve $P$ and zinc (Zn), produce siderophores and synthesize Indole Butiric Acid (IAA). In addition, other studies showed that $P$. ananatis have anta-gonistic activity against the pathogen Rhizoctonia solani [19]. P. plecoglossicida grows at $\mathrm{pH}$ ranging between 5.0-9.0 (Table 1) but, optimally at $28^{\circ} \mathrm{C}$ at a $\mathrm{pH}$ of 7.3. Some studies mentioned that $P$. plecoglossicida is one of the exopolysaccharideproducing bacteria, which play an important role in increasing the aggregate of the area around the plants root system (rhizosphere) [20, 21]. Exopolysaccharides produced by $P$. plecoglossicida protect the plant against invasion of pathogens and help in the development of nodules, release of bacteria from infection threads, bacteroid development and suppression of plant defense responses, protection against plant anti-microbial compounds [20]. B. licheniformis, is an important source of enzymes. It is a thermophilic bacterial that can survive at high temperatures $50-65^{\circ} \mathrm{C}$. These bacteria can thrive at even higher temperatures and have a wider $\mathrm{pH}$ range compared to $P$. ananatis and $P$. plecogloccicide. The optimal temperature for enzyme secretion is at $37^{\circ} \mathrm{C}$. It can survive in extreme environments by forming spores and then returning to vegetative when environmental conditions are favorable. $B$. licheniformis is a contributor to the nitrogen cycle and has anti-fungal activity. It functions as a microbial fungicide. Each bacterial's optimum $\mathrm{pH}$ becomes a consideration for optimizing the range of $\mathrm{pH}$ of consortia culture.

\section{Optimum pH}

From the current study, the optimum $\mathrm{pH}$ required by the three bacteria to grow in a consortium was 5.5 based on the $\mathrm{OD}_{600}$ (1.542) (Figure $2)$. In general, bacterial growth is influenced by environmental acidity $(\mathrm{pH})$ because each microbe requires different environmental conditions. Changes in the environmental conditi- 
Table 2. The references of optimal pH for bacteria growth in liquid biofertilizer

\begin{tabular}{llcc}
\hline & \multicolumn{1}{c}{ Bacteria } & Optimum pH & References \\
\hline N fixing bacteria & Bacillus licheniformis (SNF 5) & $<5-11.0$ & {$[23]$} \\
\hline P-soluble bacteria & Pantoea ananatis (SPP 1) & $4.0-10.0$ & {$[18]$} \\
\hline Soil stabilizing aggregate & Pseudomonas plecoglosiccida (SPE 20) & $5.0-9.0$ & {$[20]$}
\end{tabular}
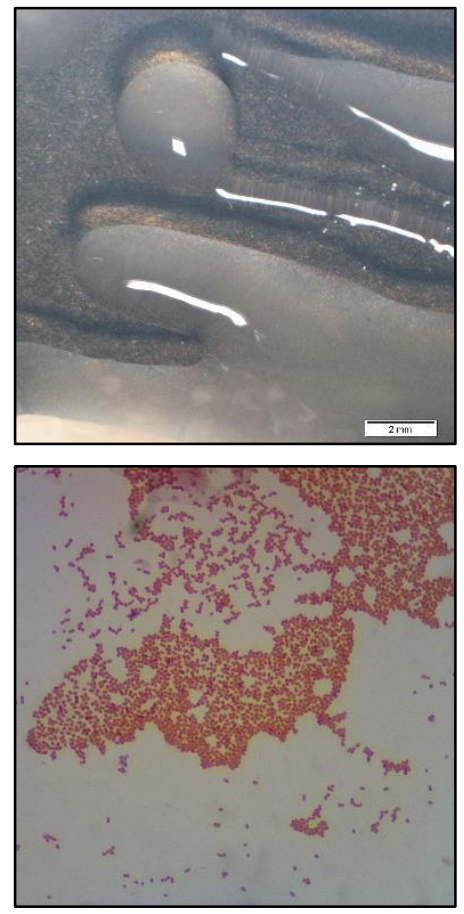

(a)
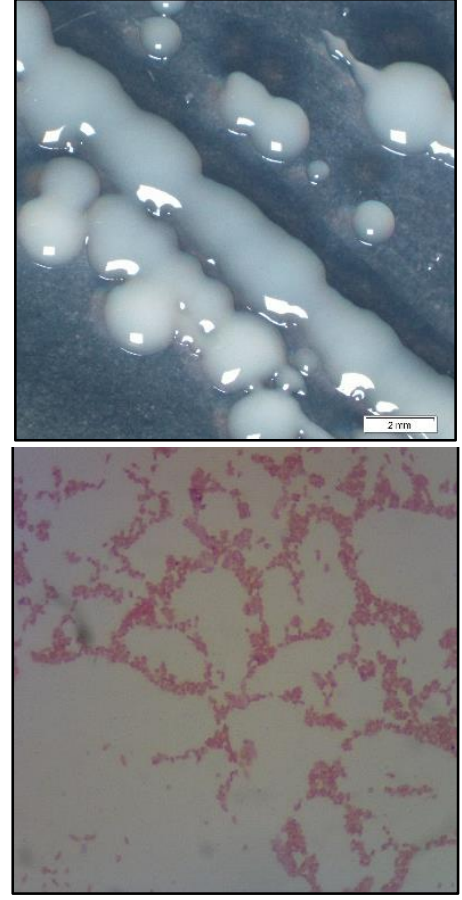

(b)
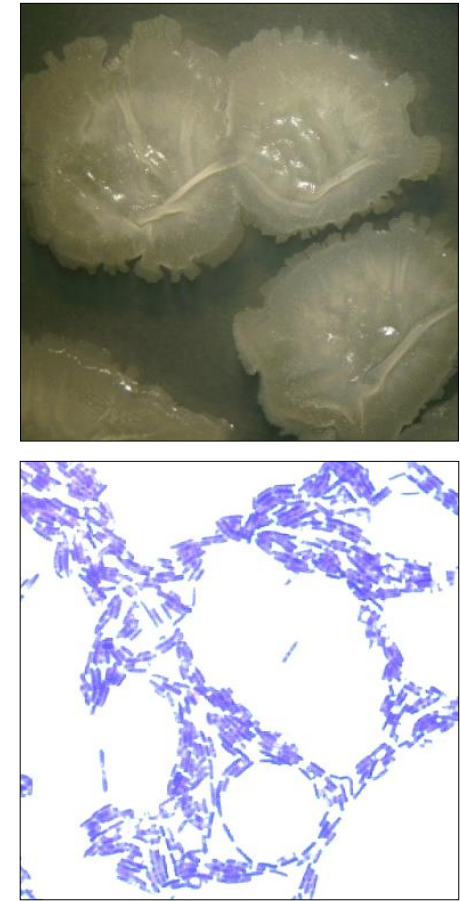

(c)

Figure 1. The purity of each isolate before use: (a) Pseudomonas plecoglossicida, (b) Pantoea ananatis and (c) Bacillus licheniformis. Above photos are single colony on a streak of three bacterial isolates and below photos are cell morphology of three bacterial isolates (no different bacterial cells on microscopic observation)

ons will affect the growth and life of bacteria at the initial phase of growth, whereby bacteria will die because they cannot carry out metabolic processes [22]. Each bacterial isolate has different $\mathrm{pH}$ conditions. In this study, bacteria were incubated within the $\mathrm{pH}$ range relevant to other studies (Table 2).

The bacteria experienced an accelerated growth phase (log phase) between 0-12 hours because the media used in the $\mathrm{pH}$ test was similar to the bacterial media culture, namely the Nutrient Broth media. Rapid bacterial adaptation resulted in the rapid stationary phase of bacterial growth. The increasing number of bacteria during the stationary phase (between the $12^{\text {th }}$ and $60^{\text {th }}$ hours) resulted in an increased return between the 60 and 72 hours. The average temperature of Malang C was about $22-25^{\circ} \mathrm{C}$. However, according to our records at the time of observation at 60-70, the temperature reached $30^{\circ} \mathrm{C}$. This might occur because the room temperature increased during the 60-72 hours storage period. The bacteria formulated in this biological fertilizer are mesophyll bacteria with optimum temperatures between $25^{\circ} \mathrm{C}-37^{\circ} \mathrm{C}$. At the $72^{\text {nd }}$ hour observation, the opti$\mathrm{mal} \mathrm{pH}$ for bacterial growth was revealed to be $\mathrm{pH}$ 5.5, implying bacterial production will increase at/after 72 hours. This observation served as a reference for the long shelf life of biological fertilizer products. Increasing the number of bacteria after 72 hours caused the $\mathrm{pH}$ of the bacterial growth media (nutrient broth) to drop to $\mathrm{pH}$ 4.5. The decrease in $\mathrm{pH}$ of the media occurred due to the formation of organic acids that affect bacterial cell metabolic activity [23]. Bacteria growing in any medium will modify the $\mathrm{pH}$ of the medium as they produce metabolite while they are growing and other organic acids and make the 
medium altered. Most common is the secretion /excretion of organic acids.

\section{Bacteria viability}

Figure 3 shows the difference in bacterial viability in each treatment. The difference in the viability results was caused by differences in the carrier material and the type of additional material in the formulation. The liquid formulation of biofertilizer treatment VP3 (vermiwash carrier with 1\% PEG added ingredients) has the highest viability during the 16 weeks storage period. Viability values VP3 are MP1 and MP2. Whereas $\mathrm{P} 0$ is a liquid medium made from commercially sold material (peptone) with recommended concentrations, having lower values than those of VP3, MP1 and MP2.
Total plate count (TPC) was used to test the microbial viability of the carrier medium based on the number of bacterial populations originating from a series of dilutions to $10^{-8}$ or to $10^{-n}$ dilutions to simplify calculations. The unit used to define total number of bacterial colonies was CFU / ml (colony forming units). The diluted liquid formulation of biofertilizer was then purified by spreading it on growing media (Nutrient Agar). In Nutrient Agar, beef extract and peptone are used as the basic ingredients because they are a source of protein, nitrogen $(\mathrm{N})$, vitamins, and carbohydrates needed by the microorganisms to grow optimally [24].

During 16 weeks of culture, bacterial viability in various biological fertilizer formulations was significantly different because of the variations in

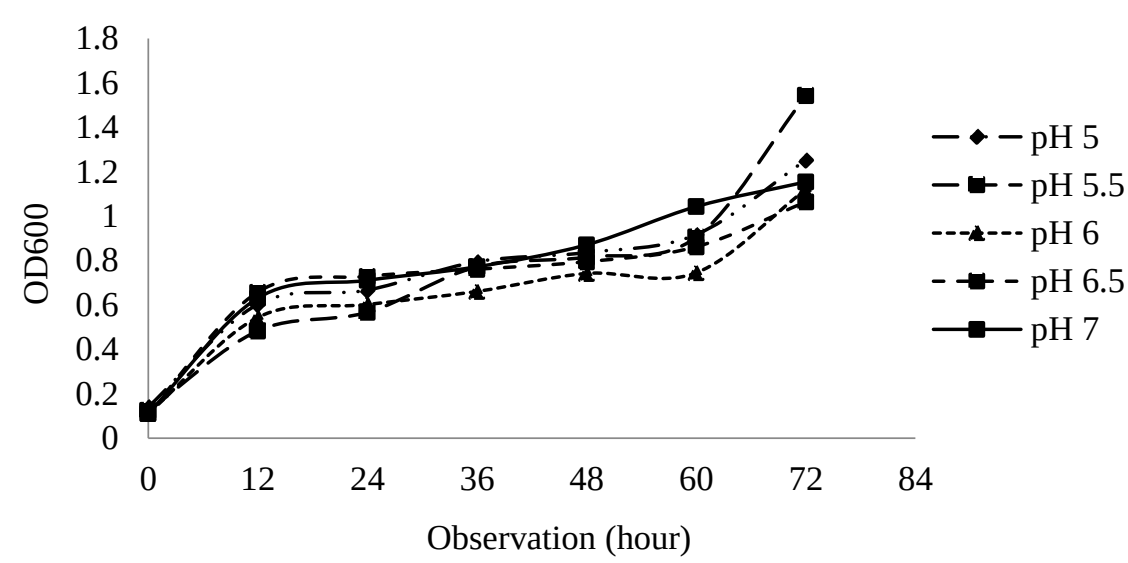

Figure 2. Consortium bacterial growth at different level of $\mathrm{pH}$ and those effect on the changes of $\mathrm{OD}_{600}$ value

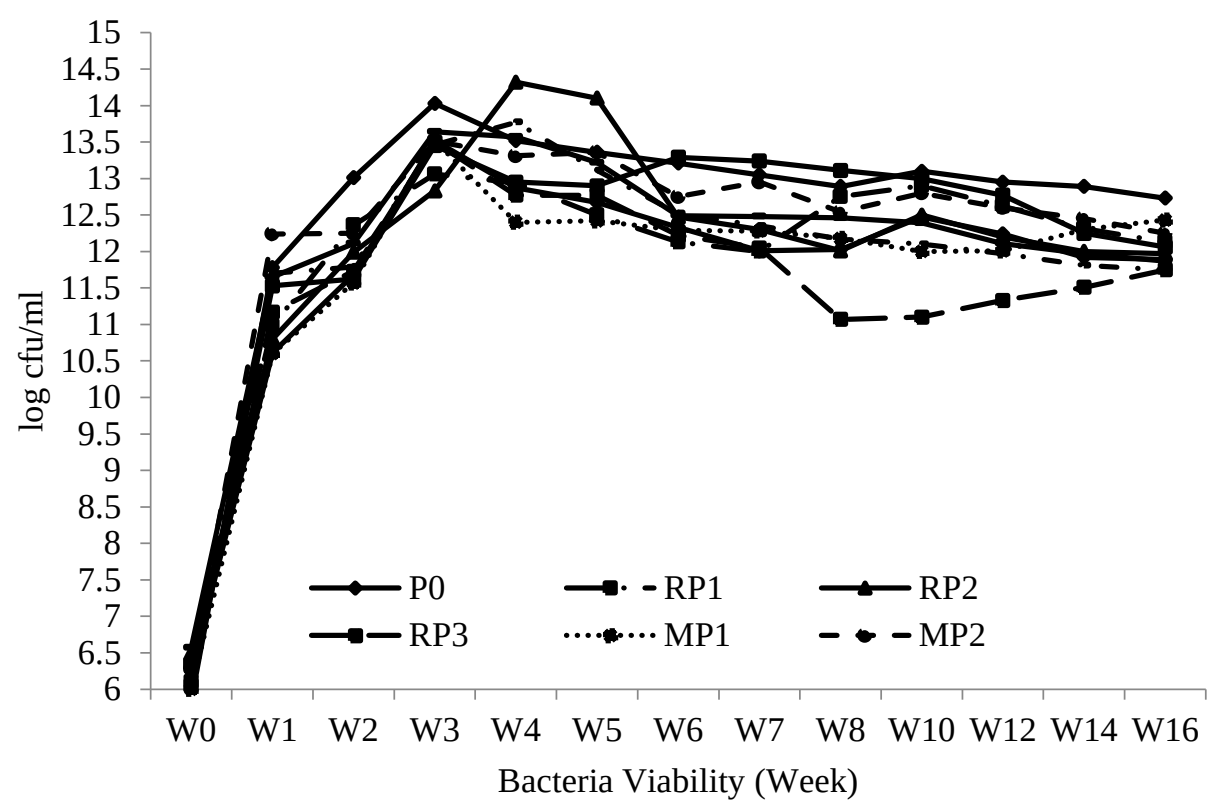

Figure 3. Bacterial viability (log CFU/ml) during 16 weeks of culture 


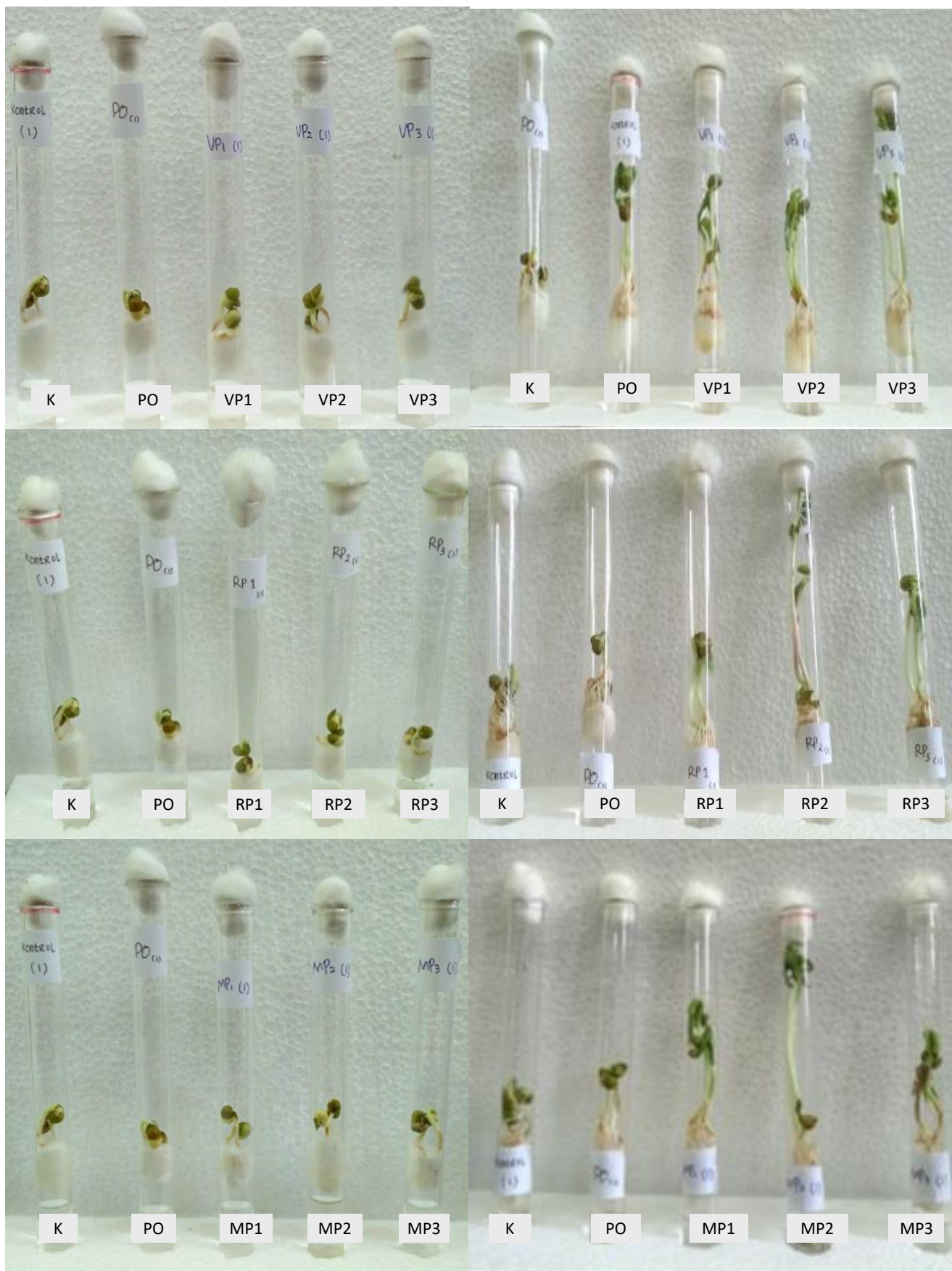

Figure 4. Pathogenesis test of all treatments on germination of green beans. The pictures on the left ( 0 days after culture) and right (5 days after culture) show no symptoms of necrosis, decay, deformity and growth inhibition

the carrier material and the type of supplementary material in the formulation. The treatment of VP3 produced higher bacterial viability compared to the other treatments. The methodology (Table 1) explains that VP3 is a liquid carrier media made from vermiwash, molasses, and PEG. Whereas MP1 and MP2 which have values below VP3, are only made from molasses plus glycerol (MP1) and
PEG (MP2). The carrier material in the VP3 formulation enhanced the viability of the bacteria because vermiwash is rich in nutrients that can maximize the survival of the bacteria during the storage period. Giyanto et al. [25], observed that vermiwash carrier material is in organic liquid waste. It demonstrated great potential as a multiplication medium for biological agents because it 
Table 3. Green bean seed growth under different formulation of biofertilizer after 5 days of germination

\begin{tabular}{ccc}
\hline \multirow{2}{*}{ Treatments } & \multicolumn{2}{c}{ Parameter } \\
\cline { 2 - 3 } & Root length $(\mathrm{cm})$ & Sprout length $(\mathrm{cm})$ \\
\hline Control & $2.64 \mathrm{a}$ & $4.74 \mathrm{a}$ \\
P0 & $2.46 \mathrm{a}$ & $4.71 \mathrm{a}$ \\
VP 1 & $2.71 \mathrm{a}$ & $5.27 \mathrm{a}$ \\
VP 2 & $2.90 \mathrm{ab}$ & $5.81 \mathrm{ab}$ \\
VP 3 & $3.58 \mathrm{c}$ & $7.75 \mathrm{c}$ \\
RP1 & $2.25 \mathrm{a}$ & $7.50 \mathrm{c}$ \\
RP2 & $2.35 \mathrm{a}$ & $9.31 \mathrm{~d}$ \\
RP3 & $2.04 \mathrm{a}$ & $6.90 \mathrm{bc}$ \\
MP1 & $5.74 \mathrm{~d}$ & $5.74 \mathrm{bc}$ \\
MP2 & $7.93 \mathrm{f}$ & $7.93 \mathrm{~cd}$ \\
MP3 & $6.99 \mathrm{e}$ & $6.99 \mathrm{bc}$ \\
\hline LSD & Sig $\left(^{*}\right)$ & Sig $\left(^{*}\right)$ \\
\hline
\end{tabular}

Note: Numbers accompanied by the same letter in the same column indicates no significant difference in the 5\% LSD test (Sig: Significant). Visually, see Figure 4 of the right side

contained nutrient compositions vital for bacterial growth, such as protein, carbohydrates, water, amino acids, fats, mineral salts, and other nutrients. The addition of PEG is also reported to increase bacteria's solubility, which is inert in liquid formulations. This material is not easily hydrolyzed and does not interfere with microbial growth [7]. In addition to the beneficial carrier material for bacterial growth and viability, the maintenance of liquid fertilizer formulations during the storage period is very important. Immersion of bacterial cells in liquid fertilizer formulations can stabilize bacterial growth. Immersion in the formulation functions to homogenize bacteria in the liquid with nutrients in the formulation. This prevents the accumulation or deposition of bacteria, nutrients and secondary metabolites at the bottom of the bottle.

\section{Pathogenicity test}

In the pathogenicity test, the three bacterial isolates grown in a consortium did not show any pathogenicity symptoms to the young green bean sprouts (Figure 4). Five days after culture, green beans were at the phase susceptible to disease, but in each treatment, the plants continued to grow well and did not show any symptoms of decay, necrosis, growth inhibition or deformities.

The mechanism of pathogeny symptoms can be detected from the ability of the pathogen to modify phenolic compounds, changes in free amino acids, chlorophyll, photosynthesis or respiration rates and plant tissue destruction at the cellular level [26]. As described in bacteria viability, the treatment of MP1 and MP2 had a viability value lower than those of VP3. However, they are shown to stimulate the growth of sprouts with markedly longer crop length compared to controls. Sprout length of MP1, MP2 and MP3 were likely longer than VP3 treatment, but the value was not significantly different. RP2 has the highest germination length, but the value was not significantly different to MP2. However, RP2 has a significantly lower bacterial viability than those of VP3.

A previous study on consortium bacteria exudate demonstrated that the Bacillus licheniformis MH48 could produce auxin that increased axial development and stimulated lateral root formation [27], producing increased nutrient content and germination Camellia oleifera seeds [28]. B. licheniformis MH48 can cause accumulation of auxin in the field soil. Other studies showed that the auxin hormone was very low in affecting the growth of root shoots [29]. Park et al., [29] report that B. licheniformis MH48 could stimulate Camellia japonica seed germination. B. licheniformis MH48 produces increased nutrient content and germination of $C$. oleifera in coastal reclamation land. In addition to B. licheniformis bacteria, Pseudomonas plecoglossicida bacteria and rock phosphate played an important role in plant growth under different fertility conditions [30]. Pantoea ananatis promotes plant growth rhizosphere bacteria capable of dissolving phosphate and zinc, producing siderophore and synthesizing IAA hormone, which can stimulate an increase in the number of lateral roots [31].

Table 3 shows that liquid formulation of biofertilizer has a significant influence on the length of the sprouts and the length of the root of the green beans. Control was same as P0, VP1 (with same code of "a"). On the other hands, both of them is not significantly different from VP2 (respectively code of "a" and "ab"). RP2 treatment (with code of "d") produced the highest growth but it is not significantly different from the MP2 treatment (with code of "cd"). The RP2 formulation consists of compost wash from seaweed, the three bacterial isolates and glycerol additives. Chemically, seaweed extract consisted of water $(27,8 \%)$, ash (22,25\%), protein (5,4\%), fat $(8,6 \%)$, carbohydrate $(33,3 \%)$ and rough fiber $(3 \%)$. In 
addition, seaweed extract also contains a variety of enzymes, amino acids, nucleic acid, vitamins (A, $\mathrm{B}, \mathrm{C}, \mathrm{D}, \mathrm{E}$ and $\mathrm{K}$ ), macro mineral (oxygen, nitrogen, selenium and calcium) and micro mineral (iron, sodium and magnesium) [32]. The MP2 formulation consists of molasses, the three bacterial isolates and glycerol additives. Molasses contains $\mathrm{N}$ and minerals which are not only beneficial for bacterial growth, but also beneficial for plants. Bacterial isolates contain growth hormones that can help the growth of green bean sprouts. Glycerol additives are useful for extending the shelf life of biological fertilizers so that the number of beneficial plants is maintained up to the time of inoculation.

\section{Conclusion}

Optimum initial $\mathrm{pH}$ for each culture (separately $B$. licheniformis, $P$. ananatis, and $P$. plecoglossicida) are different when those bacteria are mixed as consortium. The consortium requires an optimum $\mathrm{pH}$ of 5.5 for growth. The best bacterial viability is shown in the VP3 treatment (vermiwash carrier with $1 \%$ PEG additives) during the 16-week storage period. However, observations of viability over a longer period need to be done because the bacteria in the liquid formulation have not experienced a phase of death. The consortium of the three isolates during the liquid formulation of biological fertilizers did not cause pathogenic symptoms of the vegetative phase (germination phase) of green bean plants in all treatments. The results of growth of green bean sprouts on MP2 treatment showed the best growth as observed from the parameters of the length of the sprouts and root length. Furthermore, the potential and effectiveness of the biofertilizers formulated still require testing under greenhouse and field conditions before a final conclusion can be drawn.

\section{Acknowledgement}

The authors wish to thank lab members namely: Oniek, Aindah and Ristanti for their contribution and assistance with the experiment; Chesly $\mathrm{K}$ for proofreading the manuscript. Also, we would like to thank UNISMA and the RISTEK BRIN for the financial support.

\section{References}

1. Odlare M, Lindmark J, Ericsson A, Pell M (2015) Use of organic wastes in agriculture. Energy Procedia 75: 24722476. doi: 10.1016/j.egypro.2015.07.225

2. Jeni H, Aris I (2010) Viability and effectiveness of biofertlizer from several dried technique and period of storage. In Proceeding National Seminar Sains III, Biological Science: 13 November 2010; Bogor.

3. Hamida AU, Noor EN, Isnaeni (2019) Effect of sugar cane molasses and tofu waste on the inhibitory activity of cell free fermentation broth of Streptomyces antibioticus K-6. Pharmaciana 9: 315-324. doi: 10.12928/pharmaciana.v9i2.13808

4. Sinha RK (2009) Earthworm vermicompost: A powerful crop nutrient over the conventional compost \& protective soil conditioner agains the destructive chemical fertilizers for food safety and security, Am-Euras. Journal of Agriculture and Enviromental Science 5: 1-55.

5. Fornes F, Sanchez PM, Guadiola JL (2002) Effect of a seaweed extract on the productivity of 'de Nules' clementinem danarin navelina orange. Botanica Marina 45: 486-489. doi: 10.1515/BOT.2002.051

6. Prithiviraj B (2009) Seaweed extracts as biostimulants of plant growth dan development. Plant Growth Regulation 28: 386-399. doi: 10.1007/s00344-009-9103-x

7. Simonin H, Winckler P, Gros A, Perrier-Cornet JM, Gervais P (2015) How dehydration with glycerol protects bacteria cell membranes against deleterious effects of super cooling. Cryobiology 71 (3): 549. doi: 10.1016/j.cryobiol.2015.10.051.

8. Guerra-Tschuschke I, Martin I, Gonzalez MT (1991) Polyethylene Glycol-Induced Internalization of Bacteria into Fungal Protoplasts: Electron Microscopic Study and Optimization of Experimental Conditions. Applied and Environmental Microbiology 57 (5): 1516-1522. doi: 10.1128/AEM.57.5.1516-1522.1991.

9. Arfarita N, Muhibuddin A, Imai T (2019) Exploration of indigenous free nitrogen-fixing bacteria from rhizosphere of Vigna radiata for agricultural land treatment. Journal of Degraded and Mining Lands Management 6 (2): 1617-1623. doi: 10.15243/jdmlm.2019.062.1617.

10. Arfarita N, Hidayati N, Rosyidah A, Machfudz M, Higuchi T (2016) Exploration of indigenous soil bacteria producing-exopolysaccharides for stabilizing of aggregates land potential as biofertilizer. Journal of Degraded and Mining Lands Management 4 (1): 697-702. doi: 10.15243/jdmlm.2016.041.697.

11. Arfarita N, Lestari MW, Murwani I, Higuchi T (2019) Isolation of indigenous phosphate solubilizing bacteria from green bean rhizospheres. Journal of Degraded and Mining Lands Management 4 (3): 845-851. doi: 10.15243/jdmlm.2017.043.845

12. Antastia W, Safni I, Siregar AZ (2019) Effectiveness test of several types of Plant Growth Promoting Rhizobacteria (PGPR) to control sprout disease (Athelia rolfsii (Curzi)) on Soybean (Glycine max (L.) Merril) plants. Jurnal Agroekoteknologi 7 (2): 273-281.

13. Matloob AHA, Kamil SJ (2013) Biological control of bean root rot disease caused by Rhizoctonia solani under green house and field conditions. Agriculture \& Biology Journal of North America 4: 512-519.

14. Rahmani S, Forozandeh M, Mosavp M, Rezaeej A (2006) Detection of bacteria by amplifying the 16S rRNA gene with universal primers and RFLP. Medical Journal of the Islamic Republic of Iran 19 (4): 333-338.

15. Pelczar MJ, Chan ECS (2005) Elements of microbiology. Translators: Hadioetomo RS. Imas T, Tjitrosomo S, Angka SR (2008) Jakarta, UI Press.

16. Cox DR (2009) Randomization in the Design of 
Experiments. International Statistical. Review/Revue Internationale de Statistique 77 (3): 415-429.

17. Dastager SG, Deepa CK, Puneet SC, Nautiyal CS, Pandey A (2009) Isolation and characterization of plant growthpromoting strain Pantoea NII-186 from Western Ghat Forest Soil, India. Society for Applied Microbiology 49 (1): 20-25. doi: 10.1111/j.1472-765X.2009.02616.x.

18. da Silva JF, Barbosa RR, de Souza AN, da Motta OV, Teixeira GN, Carvalho VS, de Souza ALSR, de Souza Filho GA (2015) Isolation of Pantoea ananatis from sugarcane and characterization of its potential for plant growth promotion. Genetics and Molecular Research 14 (4): 15301-15311. doi: 10.4238/2015.november.30.6.

19. Yang JH, Liu HX, Zhu GM, Pan YL (2007) Diversity analysis of antagonists from rice-associated bacteria and their application in biocontrol of rice diseases. J.Appl.Microbiol 104 (1): 91-104. doi: 10.1111/j.13652672.2007.03534.x.

20. Roberson BE, Firestone MK (1992) Relationship between Desiccation and Exopolysaccharide Production in a Soil Pseudomonas sp. Applied and Environmental 58 (4): 1284-1291. doi: 10.1128/aem.58.4.1284-1291.1992.

21. Marilley L, Aragno M (1999) Phylogenetic diversity of bacterial communities differing in degree of proximity of Lolium perenne and Trifolium repens roots. Applied Soil Ecology 13: 127-136. doi: 10.1016/S09291393(99)00028-1.

22. Supriatin L (2008) Potency of antagonistic indigenous bacteria of peat land for controlling falling down disease (Sclerotium rolfsii) on soybean. PhD thesis. University of Brawijaya, Malang.

23. Soeka YS, Rahayu SH, Setianingrum N, Naiola E (2011) Ability of Bacillus licheniformis in production of protease enzyme alkaline and thermophilic. Media Litbang Kesehatan 21 (2): 89-95.

24. USU (Universitas Sumatera Utara) (2014) Evaluation of bacterial content in the air using Media Plate Count Agar (PCA) based vertical height at the Departemen of mouth surgery at RSGMP FKG USU with Total Plate Count
Methods (TPC). University of North Sumatera, Medan.

25. Giyanto A, Rustam S (2009) Study of culturing kitinolitik bacteria of Pseudomonas fluorescens and Bacillus sp. On organic waste and it's formulation as biopesticide (BIOPesticide). In Proceeding of Final Result Seminar; Bogor.

26. Morkunas I, Marzak J, Stachowiak, Stabiecki M (2005) Sucrose-induced lupine defense against Fusarium oxysporum: sucrose-stimulated accumulation of isoflavonoids as a defense response of lupine to Fusarium oxysporum. Plant Physiology and Biochemistry 43 (4): 363373. doi: 10.1016/j.plaphy.2005.02.011.

27. Park HG, Jeong MH, Ahn YS (2017a) Inoculation with Bacillus licheniformis MH48 to improve Camellia japonica seedling development in coastal lands. Turk. J. Agric 41: 381-388. doi: 10.3906/tar-1703-147.

28. Jae WS, Jun HW, Dong HK, Young SA (2019) Effect of Bacillus lichenisformis MH48 on control of foliar fungal diseases and growth promotion of Camellia oleifera seedlings in the coastal reclaimed land of Korea. MDPI 8 (1): 6-19. doi: 10.3390/pathogens8010006.

29. Park HG, Lee YS, Kim KY, Park YS, Park KH, Han TH, Park CM, Ahn YS (2017b) Inoculation with Bacillus licheniformis MH48 promotes nutrient uptake in seedlings of the ornamental plant Camellia japonica grown in Korean reclaimed coastal lands. Hortic. Sci. Technol 35 (1): 11-20. doi: 10.12972/kjhst.20170002.

30. Nishimori E, Kita T, Wakanbshi H (2000) Pseudomonas plecoglossicida the causative agent of bacterial haemorrhagic ascites of ayu (Plecoglossus altivelis). International Journal of System and Evolutionary Microbiology 50: 83-89. doi: 10.1099/00207713-50-1-83.

31. Silva HAS, Romeiro RSR, Macagnan D, Vieira BAH, Pereira MCB, Mounteer A (2015) Rhizobacterial induction of systemic resistance in tomato plants: non-specific protection and increase in enzyme activities. Biol Control 29: 288-295. doi: 10.1016/S1049-9644(03)00163-4.

32. McHugh DJ (2003) A Guide to Seaweed Industry. Rome, Fao Fisheries Technical Paper 441. 